\title{
Experimental determination of a mass loss of biomass pellets at different temperatures of the combustion chamber combusted in a stream of inert material
}

\author{
Katarzyna Kaczyńska ${ }^{1 *}$, Konrad Kaczyński ${ }^{1}$, and Piotr Pełka ${ }^{1}$ \\ ${ }^{1}$ Czestochowa University of Technology, Faculty of Mechanical Engineering and Computer Science, \\ Institute of Thermal Machinery, Poland
}

\begin{abstract}
In the herein paper, research on the mass loss of biomass pellets is presented. The research was carried out on a specially constructed test stand. In the research three types of pellet fuels were used, which were made of oak sawdust, sunflower husk and straw. The research was carried out at three different temperatures of the combustion chamber: $850^{\circ} \mathrm{C}$, $750^{\circ} \mathrm{C}$ and $650^{\circ} \mathrm{C}$. The research was carried out without inert material and mass rate flow $\mathrm{Gs}=2,5 \mathrm{~kg} / \mathrm{m}^{2} \mathrm{~s}$ and $\mathrm{Gs}=5 \mathrm{~kg} / \mathrm{m}^{2} \mathrm{~s}$. Quartz sand was the inert material. It was expected that an increase in the temperature prevailing in the combustion chamber would accelerate the process of mass loss of the biomass pellet combustion. However, the results of the experiment indicated that this is not the case in every analyzed case. The mass flow rate of inert material intensifies the combustion process and accelerates the biomass pellets made of oak sawdust mass loss, but increasing the temperature in the combustion chamber accelerates the process of biomass pellets mass loss more than the mass flow rate of inert material. Based on the experimental tests carried out, it was found that biomass can be combusted in circulating fluidized bed boilers, albeit due to the diversified chemical composition of the biomass (alkali content), the boiler should be operated in such a way as to prevent the softening and melting temperature of the ash being exceeded.
\end{abstract}

\section{Introduction}

Recent years have brought dynamic changes in the Polish and global fuel and energy balance. Above all, there is a significant increase in the share of energy from renewable sources [1]. The analysis of Poland's energy balance, its fuel conditions, age and technical condition of installations operating in the power industry and conditioned by our membership of the European Union with its increasingly restrictive environmental restrictions cause the need for huge investments in this sector of the economy. There are also many international commitments relating to the issues discussed. Fulfilling the RES obligations resulting from the climate and energy package and participation in the

\footnotetext{
* Corresponding author: kgajewska@imc.pcz.pl
} 
implementation of the $27 \%$ share of RES in final energy production in 2030 for the entire EU have been included in the project entitled the Energy Policy of Poland until 2050 [2].In addition, the Act on Renewable Energy Sources of 20 February 2015 [3] implements Directive 2009/28 / EC of the Council of the European Parliament of 23 April 2009 on the promotion of the use of energy from renewable sources. It should be noted, however, that the prospect of developing renewable energy sources in Poland is complicated due to the poor access to them. Biomass is the highest technical potential in comparison to other renewable resources available in Poland (Table 1) [4]. According to [5], the global biomass technical potential is estimated at $3 * 1015 \mathrm{PJ} /$ year. In Poland, the estimated potential is $755 \mathrm{PJ} /$ year.

Table 1. Comparison of biomass potential with other renewable energy resources in Poland [5].

\begin{tabular}{|c|c|}
\hline Resources & Technical potential [PJ / year] \\
\hline Biomass & 755 \\
\hline Sunlight & 445 \\
\hline Wind & 281 \\
\hline Geothermal Energy & 220 \\
\hline Water & 49 \\
\hline
\end{tabular}

Biomass is a product of the synthesis of carbon dioxide and water with the participation of solar energy (a product of photosynthesis) [6]. The efficiency of this process is about $1 \%$. Biomass consists of solid or liquid substances of both vegetable and animal origin that are biodegradable [3]. Biomass as an energy carrier differs from conventional fuels in both chemical and physical terms [7]. A comparison of the properties of coal and biomass indicates that they contain the same basic elements in their composition, albeit, in varying amounts. Coal has about four times less oxygen, and twice more carbon and more sulfur and nitrogen than biomass. In contrast, biomass is characterized by a high proportion of volatile parts and high humidity content. For fresh wood, total humidity is 30 to $60 \%$ in terms of mass. Comparing this value with the parameters of hard coal (humidity at the level of 2 to $12 \%$ ), this is a high content, although in brown coal it can exceed even $35 \%$. The calorific value of biomass depends on the humidity content. It is assumed that the average calorific value of biomass is almost twice lower than the heat value of hard coal, which is approx. $25 \mathrm{MJ} / \mathrm{kg}$ [8]. Biomass is also characterized by a low ash content compared to brown coal, where the ash content can range from 10 to $20 \%$. There is also low sulfur content, which does not exceed $0.1 \%$ (for brown coal $0.7-7 \%$ ) [9]. The combustion of hard coal produces ash that is rich in silicon dioxide, aluminum dioxide and iron trioxide, while the products of burning biomass mainly include silicon dioxide, calcium oxide and potassium oxide. The biomass ash therefore contains alkali metal compounds, which reduces the softening and melting temperature of the residue after combustion and can cause corrosion and accumulation of sediments on the heating surfaces of boilers [10]. Biomass also has almost three times lower bulk density compared to coals, which increases the costs of transporting the "energy unit" and expands the area necessary to store the raw material [9]. A number of processes are currently used in utilizing biomass for electricity and/or heat generation, of which combustion is the most common. Biomass can also be processed in torrefaction, gasification and liquefaction processes. The choice of the most suitable technology depends mainly on the specificity of the available biomass resources and should take the economic conditions into account [11]. So far, biomass combustion in Poland was mainly carried out in heating plants with a capacity not exceeding several MW, where mainly wood and straw were used [11].Currently, the market for highly biomassfired boilers (pellets, briquettes), which are an excellent fuel for both households and the professional power industry, is also widespread [12]. There are also technological solutions 
concerning the co-combustion of processed biomass with coal [11].Currently, boilers for biomass combustion and co-firing of biomass with coal are available in a wide range of power from a dozen to several hundred MW. Combustion can take place in several available technologies - dust, grate and fluidized bed. In the dust and grate boilers, temperatures in the combustion chamber reach values above $1000^{\circ} \mathrm{C}$. High temperature promotes the formation of nitrogen oxides, and significantly increases the probability of corrosion and build-up of sediments on boilers heating surfaces (low melting temperature of biomass combustion residues [10]).In the case of co-firing of biomass with coal in pulverized fuel boilers, one can find data showing that an increase of $1 \%$ in biomass of 40 $60 \%$ humidity (thus obtained immediately after cutting) in the fuel stream fed to the boiler for co-firing with coal causes $0.5-1 \%$ decrease in boiler efficiency. Balancing this amount requires increasing the amount of chemical energy from fossil fuels, which reduces the beneficial effects of co-combustion. Co-combustion of biomass also causes an increase in self-requirements (including more mills in motion, development of fuel transport systems or construction of biofuel preparation and drying systems [9]. Due to the fuel elasticity and high efficiency, the combustion of various types of biomass is ideally suited for fluidized bed boilers, which can be used in smaller units in combined heat and power plants as well as in large ones in the power industry. Fluidized combustion technology consists of combusting fuel particles in a bubble bed or circulation bed at a temperature of about 800$900^{\circ} \mathrm{C}$. The benefits resulting from the use of fluidal combustion with relation to traditional dust boilers is primarily a low level of nitrogen oxides, which eliminates the need for additional installations to reduce them, as well as the possibility of simultaneous combustion of various types of fuels - even those of low quality. Among the fluidized bed boilers, the combustion technology in the circulating bed is particularly distinguished. In this technology, the internal circulation of the particle of the bed material is used, resulting in intensive mixing and extended contact between the particles of fuel and gas. These boilers are characterized by a higher efficiency of the combustion process and lower emissions of sulfur and nitrogen oxides in comparison to the afore-mentioned boilers with a bubble bed [13]. At the moment, a significant number of fluidic units using a wide range of coals and biomass are operating in Poland. Performance data shows that they meet the applicable emission standards [13]. Poland has extensive experience in fluidized bed technology. In fluidized bed boilers with a bubble bed (EC Ostrołęka, Tychy, Białystok, Świecie, Kwidzyn) and not very popular fuels such as bark, straw pellets, agricultural waste and cellulose pulp are used for co-combustion technology [14]. The production of electricity from the combustion of biomass as the only fuel is implemented in only a few power units. This is exemplified by a fluidized bed boiler with a circulation bed for biomass fuel in PAK KONIN (Pątnów-Adamów-Konin power plant complex) designed by Sumitomo SHI FW. The boiler was designed to burn 100\% biomass, including $20 \%$ Agro (cherry pits, oat hulls, straw briquettes - together or separately), the basic fuel $(80 \%)$ is to constitute forest biomass [15]. Currently, the largest biomass boiler with a circulating fluidized bed in the world is also designed by Sumitomo SHI FW boiler for the Połaniec power plant. The boiler is designed for $100 \%$ biomass combustion, including $20 \%$ Agro. The Agro mixture consists of the following fuels: straw pellets, crushed straw briquettes, coconut shells, sunflower pellets. The basic fuel $(80 \%)$ is to constitute forest biomass.

\section{Objective of the work}

Fluidized combustion technology is competitive with relation to other combustion techniques and should be one of the most important directions for the development of the Polish power industry, as it allows for the solution of two important issues: limiting the emission of environmental pollution generated during combustion, while also enabling the 
combustion of inferior quality fuels, e.g. biomass. The combustion process in the fluidized bed is still an important research issue. In [16] the process of combustion of spherical briquettes (obtained in the process of grinding and compaction) of agro biomass (wheat straw and energy willow) and forest biomass (Scots pine) in the circulating fluid bed at $850^{\circ} \mathrm{C}$ was analyzed. The ignition times and temperatures, the surface temperature and the centre of the briquettes, the times of total combustion and the emission of gaseous pollutants were analyzed. It was found that agro biomass can be successfully used in boilers with a circulating fluidized bed under several conditions. Due to the chemical composition of agricultural biomass (high content of chlorine and alkaline elements) and low temperatures for softening and melting of ash, it should be combusted in boilers designed for combusting agro biomass.

The purpose of this work is to conduct a detailed analysis of the mass loss of biomass pellets combusted in a variable fluidized bed temperature. Research was conducted for three types of biomass. One of the fuels used is sunflower husk pellets, which are currently combusted at Jaworzno III Power Plant. Combustion was carried out at three temperatures of 650,750 and $850^{\circ} \mathrm{C}$. The conducted experiments may also prove helpful due to the possibility of using biomass in other processes, among others, rapid pyrolysis and gasification. The rapid biomass pyrolysis process takes place at a temperature of $450-550^{\circ} \mathrm{C}$ [17], whereas gasification requires a temperature above $750^{\circ} \mathrm{C}[18]$.

\section{Research methodology}

The research was carried out at three different temperatures in the combustion chamber: $850^{\circ} \mathrm{C}, 750^{\circ} \mathrm{C}$ and $650^{\circ} \mathrm{C}$. The research was carried out without inert material and mass rate flow $\mathrm{Gs}=2,5 \mathrm{~kg} / \mathrm{m}^{2} \mathrm{~s}$ and $\mathrm{Gs}=5 \mathrm{~kg} / \mathrm{m}^{2} \mathrm{~s}$. The inert material constituted quartz sand with a particle size of $0-63 \mu \mathrm{m}$ from the plant in Tomaszów Mazowiecki. Quartz sand of this type is used to form and supplement the fluidized bed in the Polish power industry. For all the analyzed combustion conditions, samples of each type of fuel were combusted repeatedly to determine the average loss of particle mass. This allowed the mitigation of the influence of differences in physical and chemical properties of individual samples, and above all in the composition of biomass.

\subsection{Experimental stand}

The research was carried out on a specially constructed test stand. The experimental stand made it possible to model the conditions of the circulating fluidized bed. The layout of the experimental stand is presented in Fig. 1. [19]. The basic elements of the station are as follows: an inert material container (1), a downpipe and a combustion chamber (8). In the upper part of the chamber there was a hole through which the quartz sand was fed. 


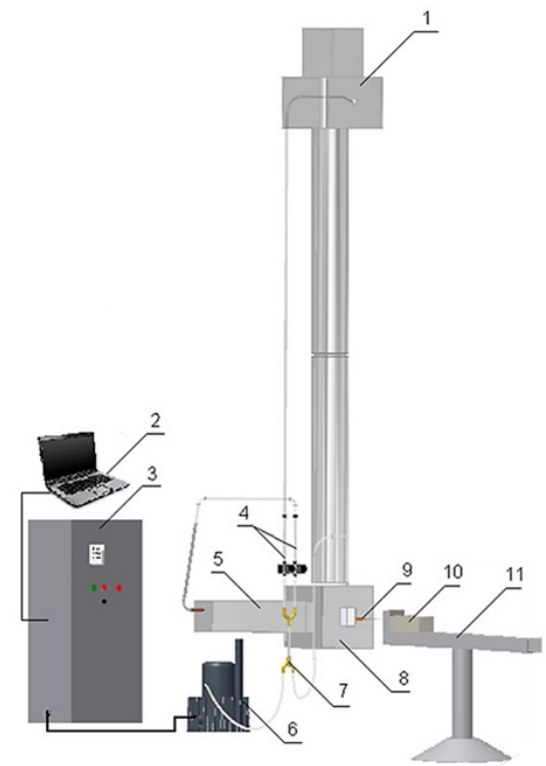

Fig. 1. The layout of the test apparatus. (1) vessel of inert material, (2) computer (3) control panel, (4) rotametres, (5) gas heater, (6) ventilator, (7) T-connector, (8) combustion chamber, (9) fuel particle, (10) tensometric branch scale, (11) support [19].

\subsection{Parameters of samples}

The research used pellets made of biomass in the shape of a cylinder made of oak sawdust, straw and sunflower husks. These fuels are available on the market. Sunflower husk pellets are used in Jaworzno III Power Station and they were also obtained from there. The mass of samples selected from the total material was $0.73 \pm 0.03 \mathrm{~g}$. Oak and straw sawdust pellets had a diameter of $6 \mathrm{~mm}$. In contrast, the diameter of sunflower husk pellets was $8 \mathrm{~mm}$. Table 2 presents the results of technical analysis of the fuels tested. The content of volatile parts and moisture in the case of biomass, depending on its type, amounted to $80-90 \%$. The lowest ash content is obtained from oak sawdust pellets (1\%), pellets from sunflower husk $4.5 \%$, while about $12 \%$ for straw pellets.

Table 2. Results of technical analysis of biomass fuels and coal from the Sobieski mine [20].

\begin{tabular}{|c|c|c|c|c|c|}
\hline Fuel type & $\begin{array}{c}\text { Volatile } \\
\text { matter } \\
{[\%]}\end{array}$ & $\begin{array}{c}\text { Moisture } \\
{[\%]}\end{array}$ & $\begin{array}{c}\text { Ash } \\
{[\%]}\end{array}$ & $\begin{array}{c}\text { Fixed coal } \\
{[\%]}\end{array}$ & $\begin{array}{c}\text { Heat of } \\
\text { combustion } \\
{[\mathrm{MJ} / \mathrm{kg}]}\end{array}$ \\
\hline $\begin{array}{c}\text { pellets from oak } \\
\text { sawdust }\end{array}$ & 79.6 & 8.7 & 1.2 & 10.5 & 18.2 \\
\hline $\begin{array}{c}\text { pellets from } \\
\text { sunflower husk }\end{array}$ & 73.8 & 8.4 & 5.5 & 12.3 & 19.8 \\
\hline straw pellets & 71.8 & 8.7 & 12.2 & 7.3 & 16.2 \\
\hline
\end{tabular}




\section{The results of experimental research}

\section{Analysis of the influence of temperature in the combustion chamber on the rate of mass loss of biomass pellets combusted in the atmosphere of air}

The first part of research was carried out at three different temperatures in the combustion chamber: $850^{\circ} \mathrm{C}, 750^{\circ} \mathrm{C}$ and $650^{\circ} \mathrm{C}$. The biomass pellets were combusted in the air atmosphere without the use of inert material. The stages of biomass pellet combustion include particle heating, humidity separation, degassing and combustion of volatiles, followed by ignition and combustion of solid combustible parts. Fig. 2 shows the stages of biomass combustion.
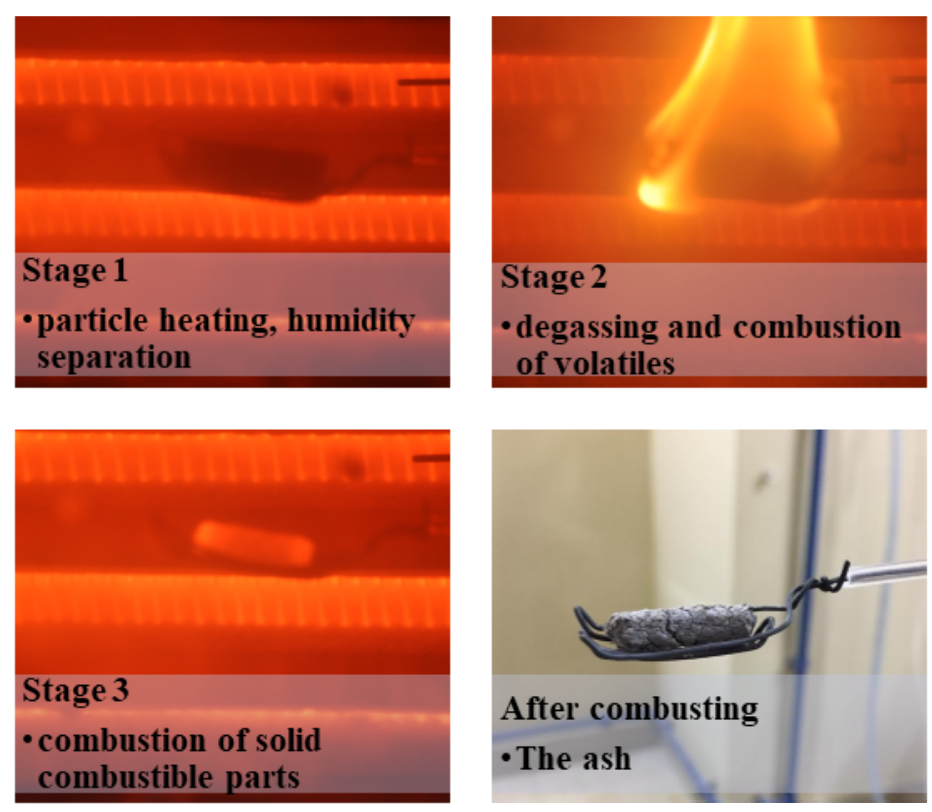

Fig. 2. Stages of combustion of pellets of biomass in air atmosphere without the use of inert material.

Fig. 3., 4. and 5. show an averaged loss of mass of oak sawdust pellet, sunflower husk and straw respectively for the three analyzed temperatures prevailing in the combustion chamber. As expected, the diagrams indicate that lowering the temperature in the combustion chamber results in a longer particle combustion time. At $850^{\circ} \mathrm{C}$ the ignition of volatile parts takes place almost immediately after placing the sample in the combustion chamber. Combustion of volatile parts at $850^{\circ} \mathrm{C}$ takes place more intensively than at lower temperatures, which takes about 40-50 seconds, while about 60 seconds at other temperatures. The diagram shown in Fig. 6. shows the combustion times when the combustion chamber temperature is reduced compared to the reference temperature $\left(850^{\circ} \mathrm{C}\right)$ for all types of pellets. 


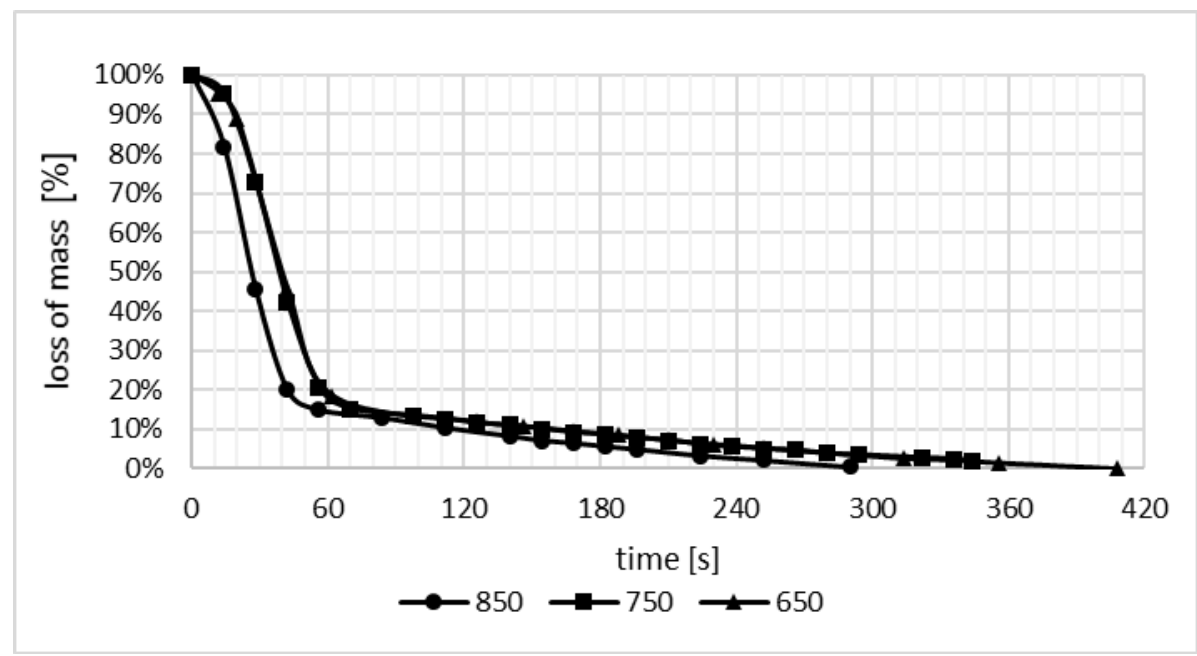

Fig. 3. Comparison of averaged mass losses of oak sawdust pellets combusted at different temperatures without the use of inert material.

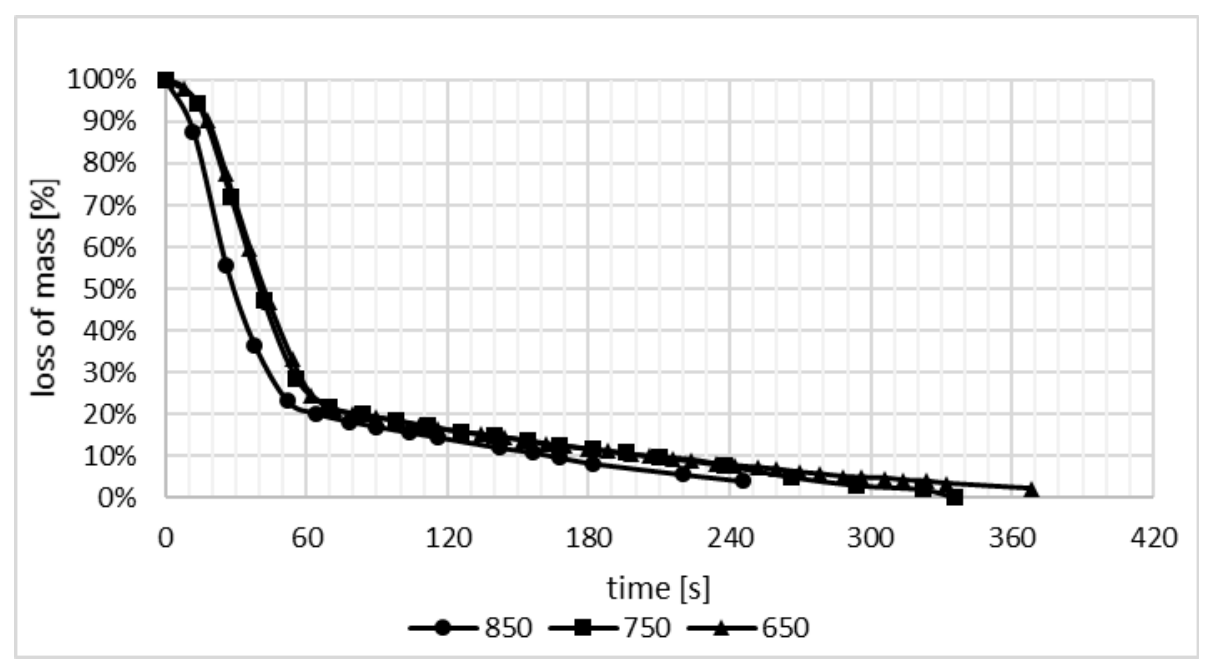

Fig. 4. Comparison of averaged mass losses of sunflower husk pellets combusted at different temperatures without the use of inert material. 


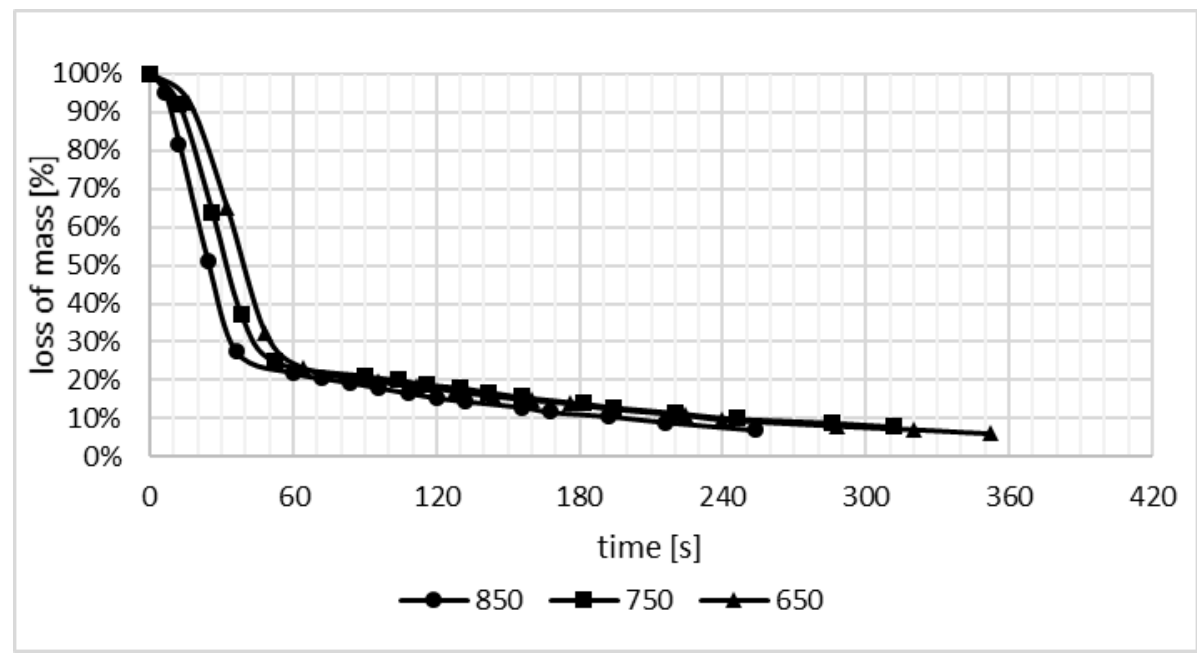

Fig. 5. Comparison of averaged mass losses of straw pellets combusted at different temperatures without the use of inert material.

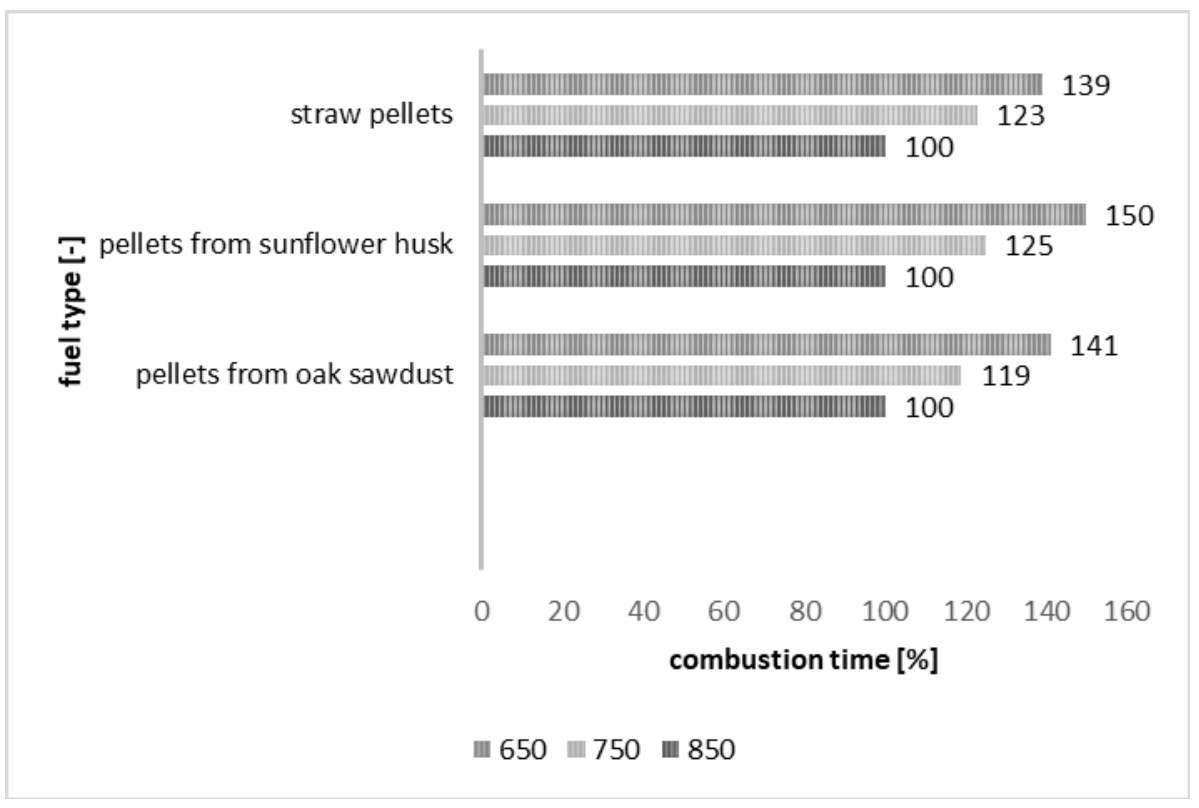

Fig. 6. Percentage comparison of pellet combustion time after lowering of the combustion chamber temperature compared to the reference temperature $\left(850^{\circ} \mathrm{C}\right)$.

\section{Analysis of the influence of the temperature prevailing in the combustion chamber on the rate of mass loss of the pellet of biomass combusted in the stream of inert material}

The second stage of experimental research included the combustion of pellets of biomass in a stream of inert material. The stages of combustion pellets of biomass in the stream of inert material are presented in Fig. 7. Compared to the photographs showing combustion without inert material (Fig. 2.) it should be noted that the volatile parts on the upper surface ignite first, i.e. in the place where the heated sand particles come in contact with the combusted 
pellets. The shape of the flame also changes, which along with the two-phase flow is directed convectionally down the chamber. After the combustion of the volatile parts, the upper surface of the pellet is weakened by the contacting particles of inert material as seen in the form of sparks emitted from the surface of the pellet. An important difference is also the lack of ash on the surface of the pellet, which is removed by the interaction of inert material. During the process of combustion under these conditions, the breakdown of fuel particles is frequently observed as a result of mechanical interactions, which cause greater susceptibility to secondary fragmentation.
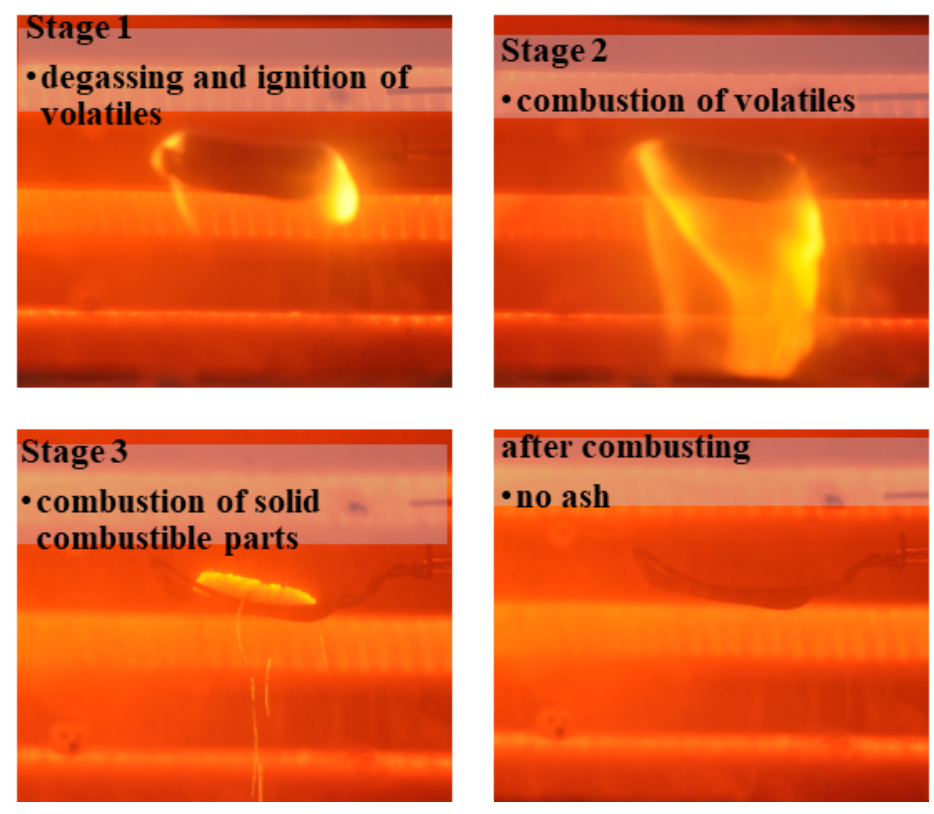

Fig. 7. Stages of combustion of pellets of biomass in air atmosphere and in a stream of inert material

Analyzing the comparison of the mass loss of pellets from oak sawdust pellets combusted at different temperatures and $\mathrm{Gs}=2.5 \mathrm{~kg} / \mathrm{m}^{2} \mathrm{~s}$ (Fig. 8.), it is clearly visible that lowering the temperature in the combustion chamber results in the longer combustion time of pellets, which is characteristic for the combustion of coal. In the case of combustion of sunflower husk pellets (Fig. 9.), the longest duration of combustion is at $850^{\circ} \mathrm{C}$. At this temperature, the phenomenon of ash softening is manifested by the sticking of sunflower husk pellets through quartz sand. The sand forms a durable surface surrounding the incinerated pellet, consequently preventing the oxidizer from entering the combusted pellet. A graph of the loss of mass of sunflower husk pellets at $850^{\circ} \mathrm{C}$ indicates the incomplete combustion of the sample. The mass of the shell produced is visible in the graph, as shown in Fig. 11. A similar effect was observed when combusting straw pellets (Fig. 10) at $850^{\circ} \mathrm{C}$, whereby the combustion time is the longest and amounts to 230 seconds. Straw pellets combusted at $850^{\circ} \mathrm{C}$ were sintered. A graph of a loss of mass at this temperature, as in the combustion of sunflower husk pellets, indicates the incomplete combustion of the sample. The graph shows the sinter mass, which is shown in Fig. 12 . The combustion time at $650^{\circ} \mathrm{C}$ amounts to 216 seconds. 


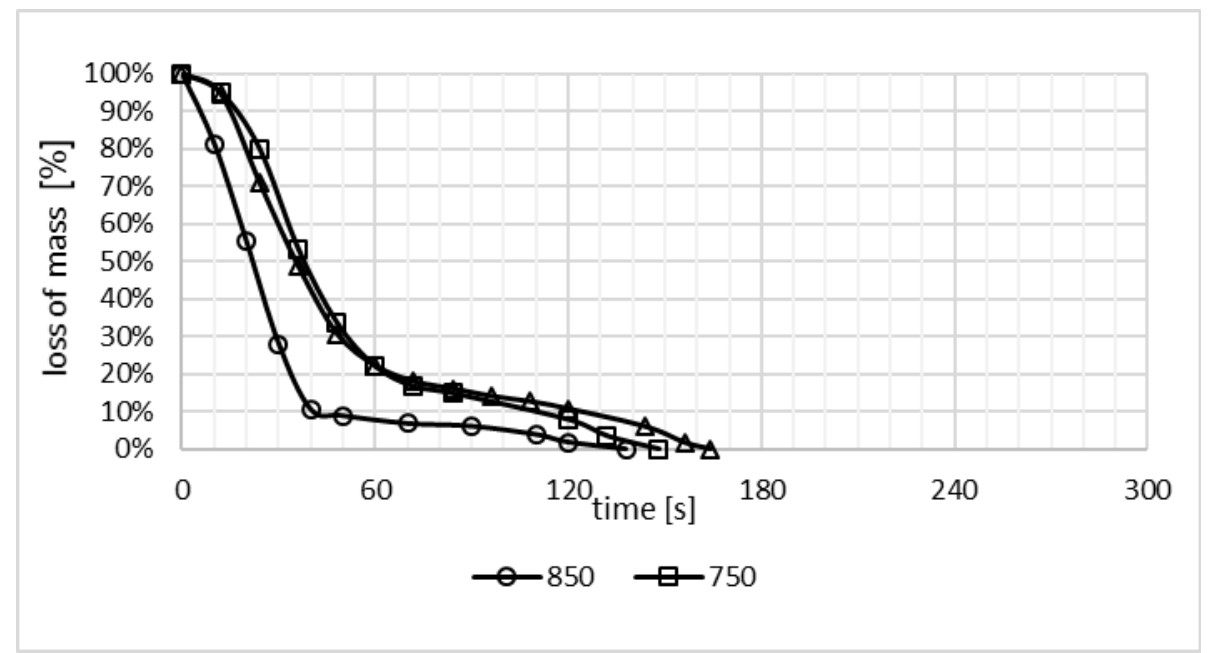

Fig. 8. Comparison of averaged mass losses of pellets from oak sawdust combusted at different temperatures at $\mathrm{Gs}=2,5 \mathrm{~kg} / \mathrm{m}^{2} \mathrm{~s}$;

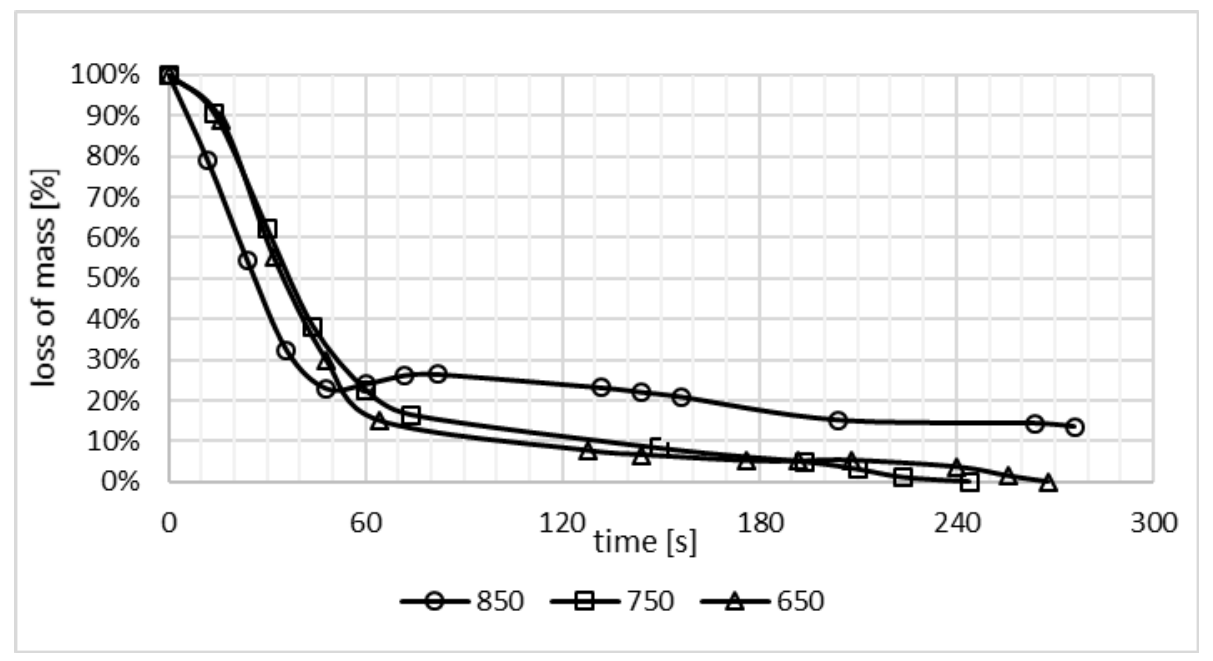

Fig. 9. Comparison of averaged mass losses of pellets from sunflower husk combusted at different temperatures at $\mathrm{Gs}=2,5 \mathrm{~kg} / \mathrm{m}^{2} \mathrm{~s}$; 


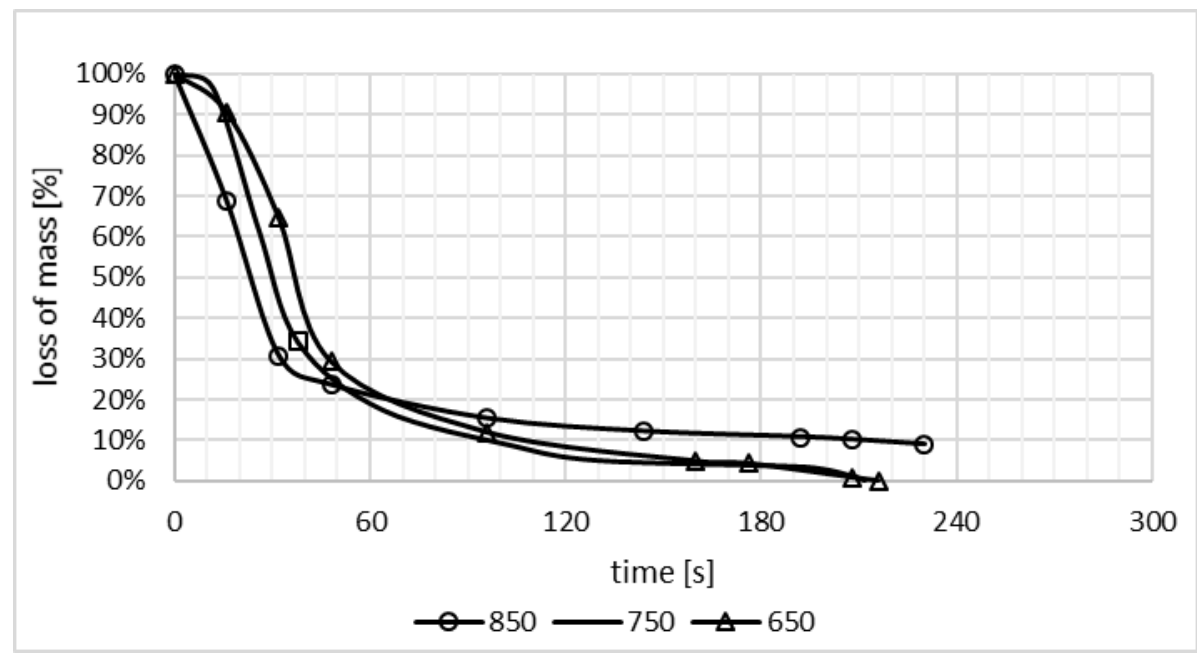

Fig. 10. Comparison of averaged mass losses of straw pellets combusted at different temperatures at $\mathrm{Gs}=2,5 \mathrm{~kg} / \mathrm{m}^{2} \mathrm{~s}$

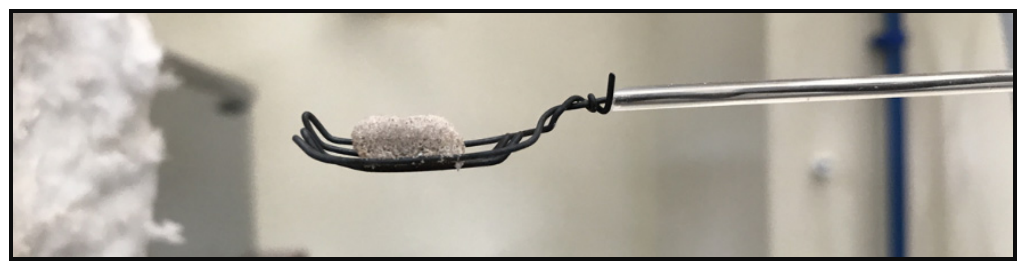

Fig. 11. The residue after combusting sunflower husk pellet at $850^{\circ} \mathrm{C}$, tests were carried out on the stream of inert material at $\mathrm{Gs}=2,5 \mathrm{~kg} / \mathrm{m}^{2} \mathrm{~s}$.

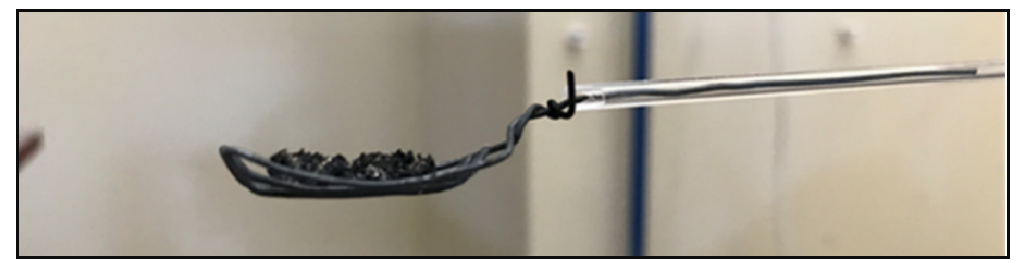

Fig. 12. The residue after combusting straw pellet at $850^{\circ} \mathrm{C}$, tests were carried out on the stream of inert material at $\mathrm{Gs}=2,5 \mathrm{~kg} / \mathrm{m}^{2} \mathrm{~s}$.

The graph shown in Fig. 13. indicates the combustion times after the lowering of the combustion chamber temperature compared to the reference temperature $\left(850^{\circ} \mathrm{C}\right)$ of all types of pellets combusted in the inert material stream at Gs $=2.5 \mathrm{~kg} / \mathrm{m}^{2} \mathrm{~s}$. 


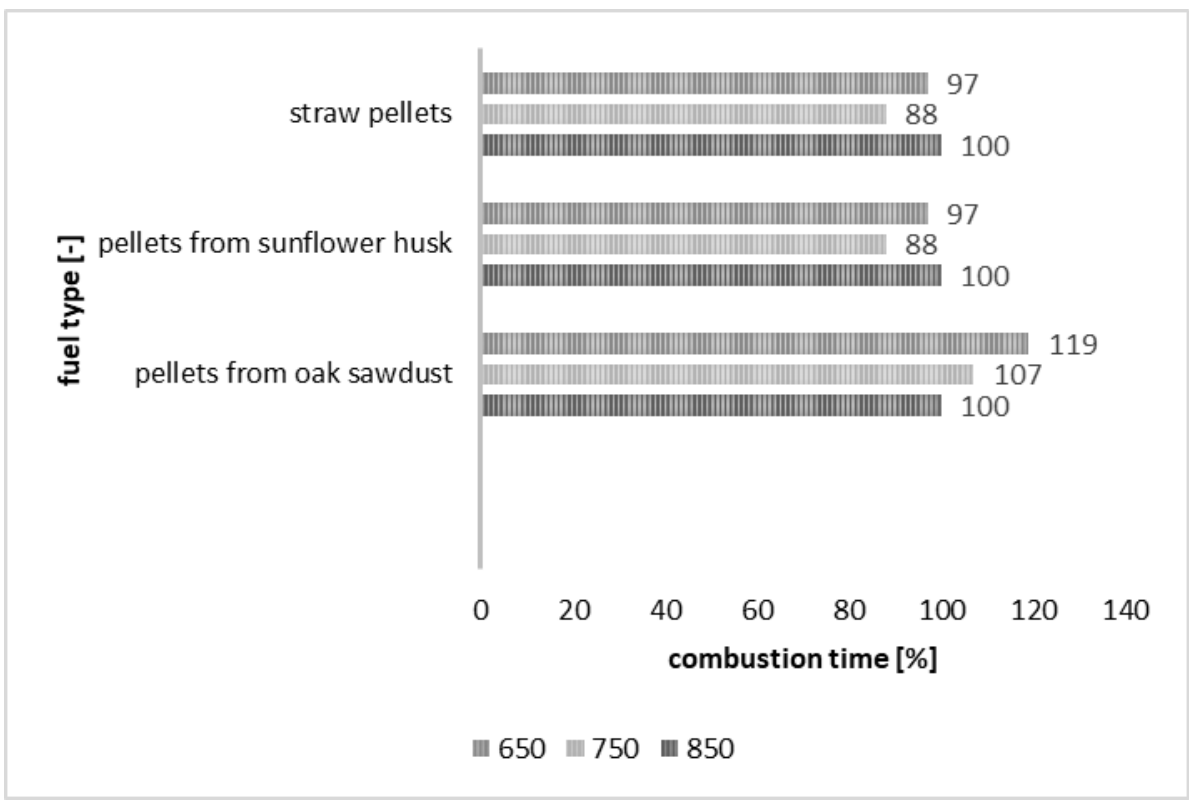

Fig. 13. Percentage comparison of pellet combustion time after lowering of the combustion chamber temperature compared to the reference temperature $\left(850^{\circ} \mathrm{C}, \mathrm{Gs}=2,5 \mathrm{~kg} / \mathrm{m}^{2} \mathrm{~s}\right.$. $)$.

Analysing the comparison of mass losses of oak sawdust pellets combusted at different temperatures and increased to Gs $=5 \mathrm{~kg} / \mathrm{m}^{2} \mathrm{~s}$, the stream of inert material (Fig. 14.) shows that, as expected, lowering the temperature in the combustion chamber results in longer combustion time. However, it is different in the case of sunflower pellets and straw pellets combusting (Fig. 15. and 16.) where combustion lasts for the longest time at $750^{\circ} \mathrm{C}$. The graph shown in Fig. 17. shows a comparison of combustion times after lowering the temperature of the combustion chamber compared to the reference temperature $\left(850^{\circ} \mathrm{C}\right)$ of all types of pellets combusted in the stream of inert material at $\mathrm{Gs}=$ $5 \mathrm{~kg} / \mathrm{m}^{2} \mathrm{~s}$.

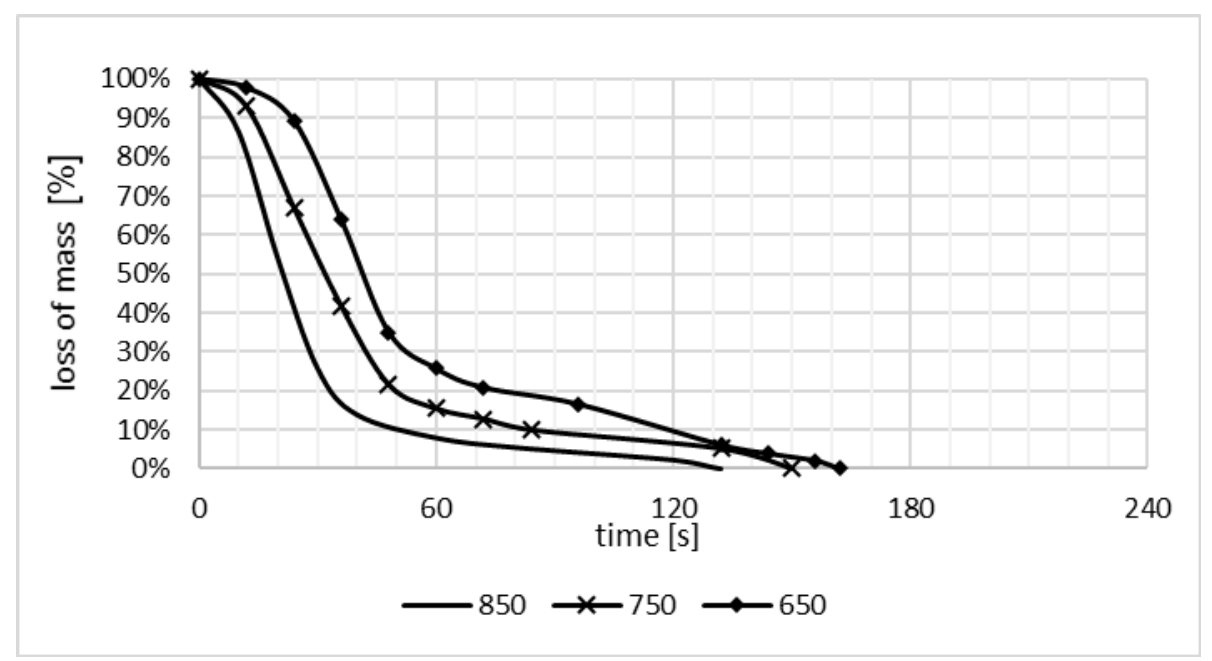

Fig. 14. Comparison of averaged mass losses of pellets from oak sawdust combusted at different temperatures at $\mathrm{Gs}=5 \mathrm{~kg} / \mathrm{m}^{2} \mathrm{~s}$; 


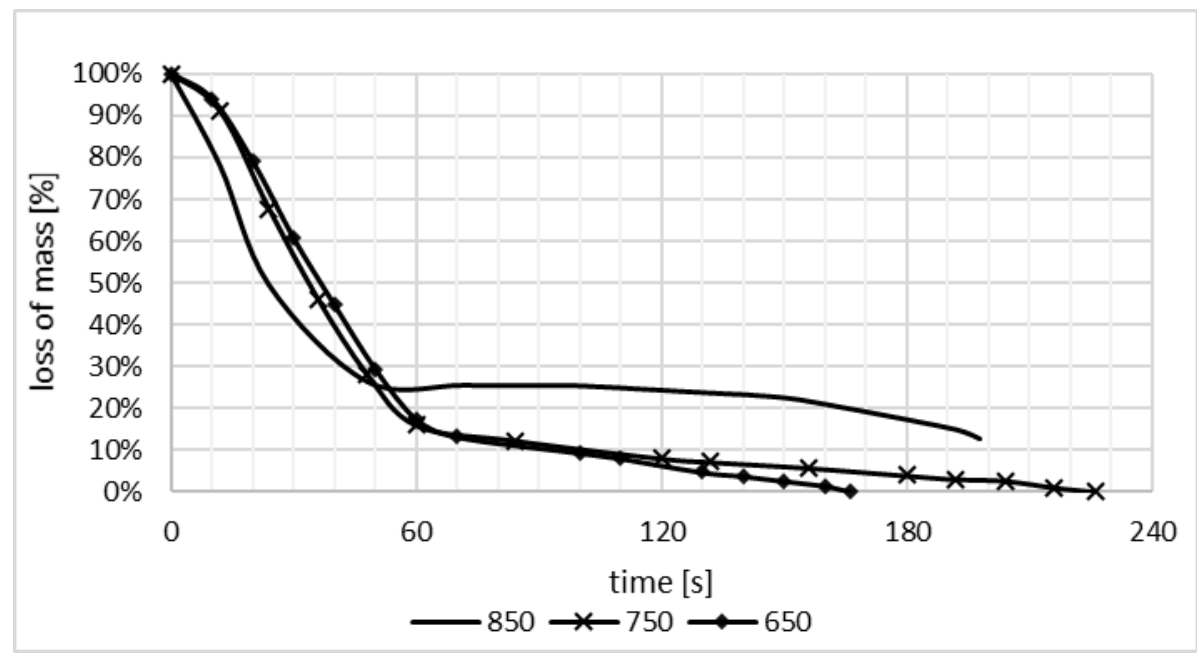

Fig. 15. Comparison of averaged mass losses of pellets from sunflower husk combusted at different temperatures at $\mathrm{Gs}=5 \mathrm{~kg} / \mathrm{m}^{2} \mathrm{~s}$;

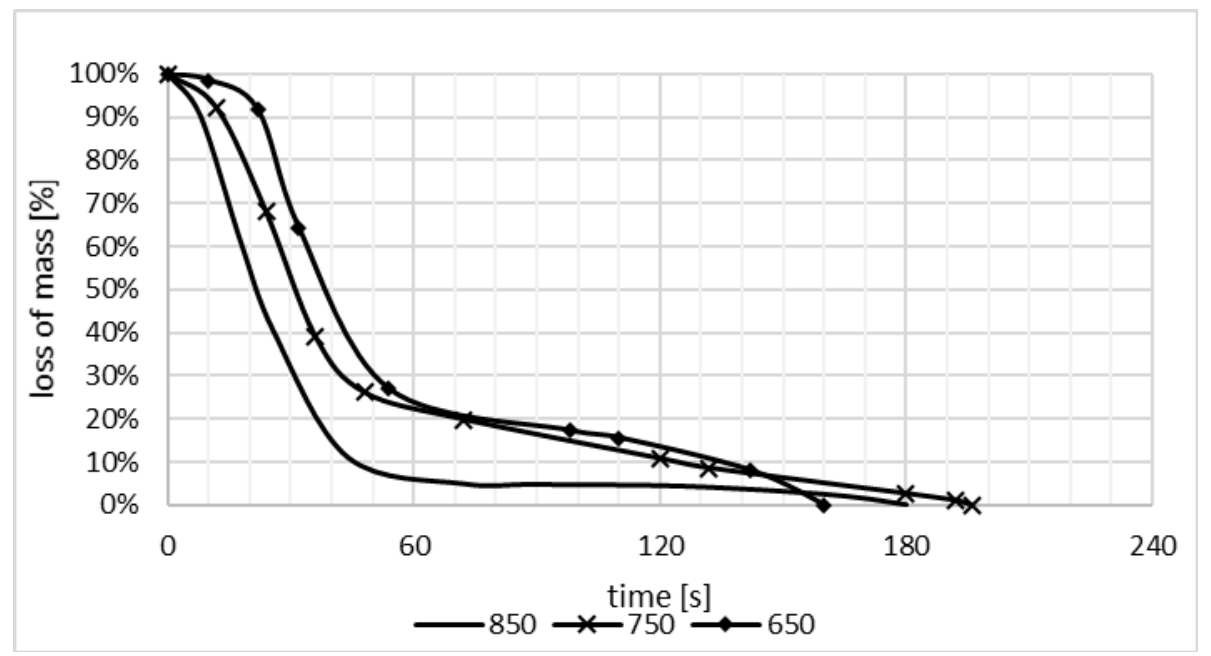

Fig. 16. Comparison of averaged mass losses of straw pellets combusted at different temperatures at $\mathrm{Gs}=5 \mathrm{~kg} / \mathrm{m}^{2} \mathrm{~s}$; 


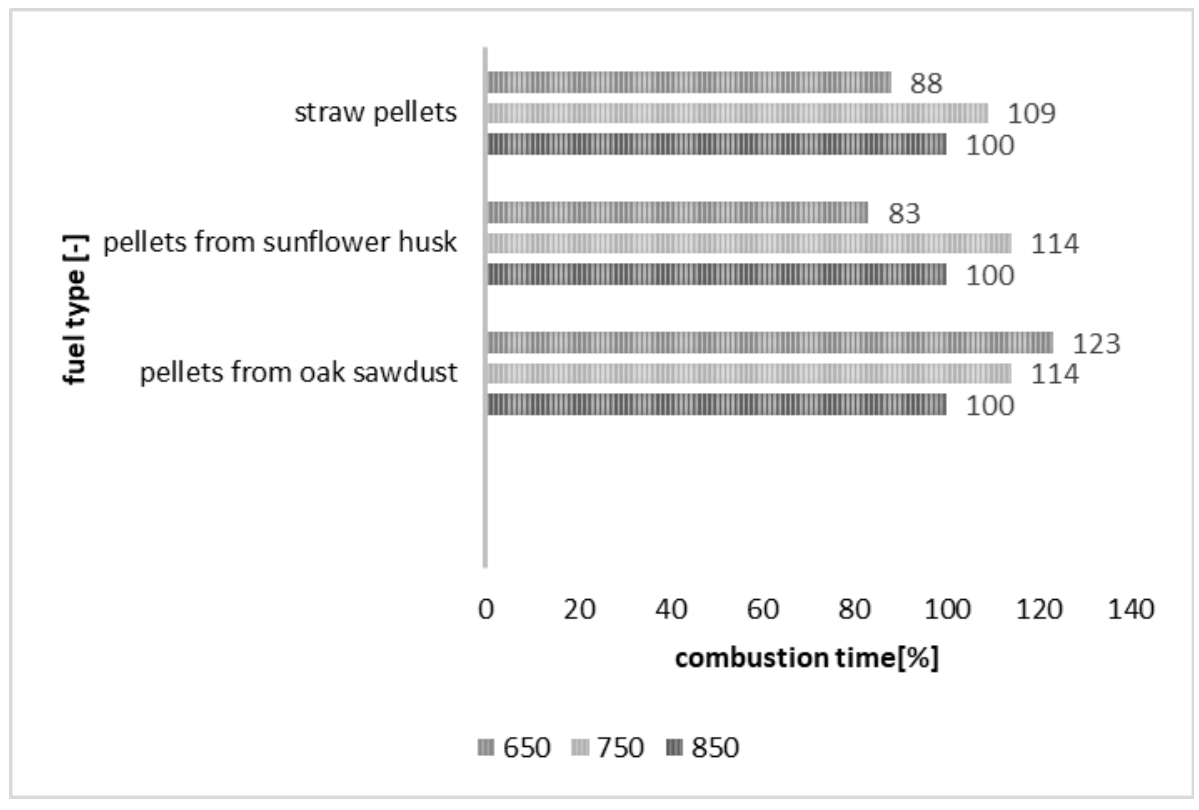

Fig. 17. Percentage comparison of pellet combustion time after lowering of the combustion chamber temperature compared to the reference temperature $\left(850^{\circ} \mathrm{C}, \mathrm{Gs}=5 \mathrm{~kg} / \mathrm{m}^{2} \mathrm{~s}\right.$. ).

\section{Comparison of combustion time depending on the value of the inert material stream}

Table 3 presents a list of combustion times depending on the Gs material stream value for oak sawdust pellets combusted at different temperatures. The presence of inert material accelerates the mass loss of pellets, as it increases the amount of air directly reaching the pellet by means of removing ash and gas combustion products from the surface. As a result of the inert material stream, the diffusion process in the reaction area is intensified, and the chemical reaction constantly increases. Compared with incineration without inert material, the combustion time at a temperature of $650^{\circ} \mathrm{C}$ and a stream of inert material $\mathrm{Gs}=2.5$ $\mathrm{kg} / \mathrm{m}^{2} \mathrm{~s}$ shortened by 244 seconds, at $750^{\circ} \mathrm{C}$ by $196 \mathrm{~s}$, and at $850^{\circ} \mathrm{C}$ by 152 seconds. Increasing the stream of inert material to $\mathrm{Gs}=2.5 \mathrm{~kg} / \mathrm{m}^{2} \mathrm{~s}$ to a negligible degree accelerates the combustion process. In comparison with incineration in the stream of inert material Gs $=2.5 \mathrm{~kg} / \mathrm{m}^{2} \mathrm{~s}$, the combustion time at $650^{\circ} \mathrm{C}$ and the stream of inert material $\mathrm{Gs}=5 \mathrm{~kg} / \mathrm{m}^{2} \mathrm{~s}$ is shortened by 2 seconds, while at $750^{\circ} \mathrm{C}$ it is even more, by $2 \mathrm{~s}$, and at $850^{\circ} \mathrm{C}$, shortened by 6 seconds. Thus, it may be stated that the change in the flow of inert material to a lesser extent affects the combustion process than the change in temperature in the combustion chamber, as increasing the stream of inert material no longer changes the mechanism of combustion pellets, but only intensifies it. Table 4 presents a summary of combustion times depending on the value of the Gs material flow for pellets from sunflower husk combusted at different temperatures. Compared to incineration without inert material, the combustion time at $650^{\circ} \mathrm{C}$ and the inert material stream Gs $=2.5 \mathrm{~kg} / \mathrm{m}^{2} \mathrm{~s}$ is reduced by 100 seconds, at a temperature of $750^{\circ} \mathrm{C}$ by 124 seconds, and at a temperature of $850^{\circ} \mathrm{C}$, the combustion time increased by 30 seconds. In comparison to incineration in the stream of inert material $\mathrm{Gs}=$ $2.5 \mathrm{~kg} / \mathrm{m}^{2} \mathrm{~s}$, the combustion time at $650^{\circ} \mathrm{C}$ and the stream of inert material $\mathrm{Gs}=5 \mathrm{~kg} / \mathrm{m}^{2} \mathrm{~s}$ decreased by 102 seconds, at $750^{\circ} \mathrm{C}$ by 18 seconds, and at $850^{\circ} \mathrm{C}$ it shortened by 78 seconds. In this case, increasing the intensity of the inert material stream caused the destruction of the shell produced by the quartz sand in the initial stage of carbazinate 
combustion (Fig. 18). Table 5 presents a list of combustion times depending on the value of the Gs material stream for straw pellets combusted at different temperatures. During the combustion of straw pellets at temperatures $650^{\circ} \mathrm{C}$ and $750^{\circ} \mathrm{C}$, the inert material intensifies the combustion process. However, contrary to expectations at $850^{\circ} \mathrm{C}$, the longest straw combustion time in the stream of inert material $\mathrm{Gs}=2.5 \mathrm{~kg} / \mathrm{m}^{2} \mathrm{~s}$ is caused by the formation of a coating around the combusted pellet of quartz sand, which hinders the stream of oxidant to the pellet. Increasing the stream of inert material to $\mathrm{Gs}=5 \mathrm{~kg} / \mathrm{m}^{2} \mathrm{~s}$ causes the grinding of the shell, which affects the acceleration of the combustion process.

Table 3. Combustion times based on the value of Gs material stream for oak sawdust pellets combusted at different temperatures.

\begin{tabular}{|c|c|c|c|c|c|}
\hline Temperature $\left[{ }^{\circ} \mathrm{C}\right]$ & $\begin{array}{c}\text { Combustion } \\
\text { time } \\
\text { Gs }=0 \mathrm{~kg} / \mathrm{m}^{2} \mathbf{s} \\
{[\mathrm{s}]}\end{array}$ & $\begin{array}{c}\text { Combustion } \\
\text { time } \\
\text { Gs }=2,5 \mathrm{~kg} / \mathrm{m}^{2} \mathrm{~s} \\
{[\mathrm{~s}]}\end{array}$ & 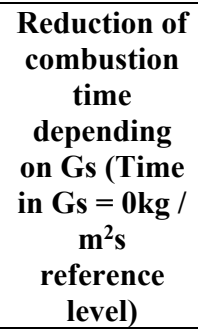 & $\begin{array}{c}\text { Combustion } \\
\text { time } \\
\mathrm{Gs}=\mathbf{5 \mathrm { kg } / \mathrm { m } ^ { 2 } \mathrm { s }} \\
{[\mathrm{s}]}\end{array}$ & $\begin{array}{c}\begin{array}{c}\text { Reduction of } \\
\text { combustion } \\
\text { time } \\
\text { depending }\end{array} \\
\text { on Gs (Time } \\
\text { in Gs }=0 \mathrm{~kg} / \\
\text { m }^{2} \mathbf{s} \\
\text { reference } \\
\text { level) }\end{array}$ \\
\hline 850 & 290 & 138 & $52 \%$ & 132 & $54 \%$ \\
\hline 750 & 344 & 148 & $57 \%$ & 150 & $56 \%$ \\
\hline 650 & 408 & 164 & $60 \%$ & 162 & $60 \%$ \\
\hline
\end{tabular}

Table 4. Combustion times based on the value of Gs material stream for sunflower husk pellets combusted at different temperatures.

\begin{tabular}{|c|c|c|c|c|c|}
\hline Temperature $\left[{ }^{\circ} \mathrm{C}\right]$ & 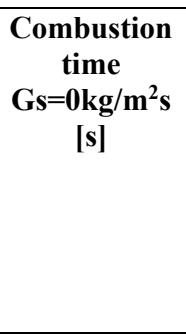 & $\begin{array}{c}\underset{\text { Combustion }}{\text { time }} \\
\mathrm{Gs}=2,5 \mathrm{~kg} / \mathrm{m}^{2} \mathrm{~s} \\
{[\mathrm{~s}]}\end{array}$ & $\begin{array}{c}\text { Reduction of } \\
\text { combustion } \\
\text { time } \\
\text { depending } \\
\text { on Gs (Time } \\
\text { in Gs }=0 \mathrm{~kg} / \\
\text { m }^{2} \mathbf{s} \\
\text { reference } \\
\text { level) }\end{array}$ & 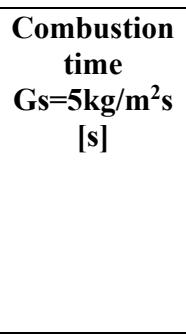 & 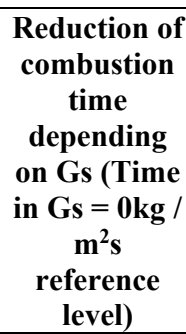 \\
\hline 850 & 246 & 276 & $-12 \%$ & 198 & $20 \%$ \\
\hline 750 & 325 & 244 & $34 \%$ & 226 & $39 \%$ \\
\hline 650 & 368 & 268 & $27 \%$ & 166 & $55 \%$ \\
\hline
\end{tabular}

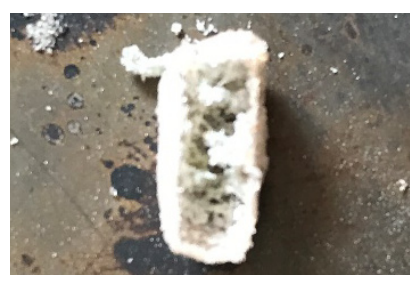

Fig. 18. Residue after combusting sunflower husk pellets at $850^{\circ} \mathrm{C}$ and $\mathrm{Gs}=5 \mathrm{~kg} / \mathrm{m}^{2} \mathrm{~s}$. 
Table 5. Combustion times based on the value of Gs material stream for straw pellets combusted at different temperatures.

\begin{tabular}{|c|c|c|c|c|c|}
\hline Temperature $\left[{ }^{\circ} \mathrm{C}\right]$ & $\begin{array}{c}\text { Combustion } \\
\text { time } \\
\text { Gs }=0 \mathrm{~kg} / \mathrm{m}^{2} \mathrm{~s} \\
{[\mathrm{~s}]}\end{array}$ & $\begin{array}{c}\text { Combustion } \\
\text { time } \\
\mathrm{Gs}=2,5 \mathrm{~kg} / \mathrm{m}^{2} \mathrm{~s} \\
{[\mathrm{~s}]}\end{array}$ & 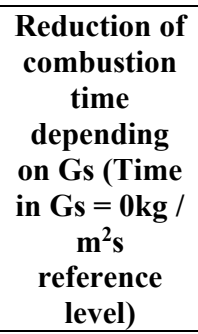 & $\begin{array}{c}\text { Combustion } \\
\text { time } \\
\text { Gs }=5 \mathrm{~kg} / \mathrm{m}^{2} \mathrm{~s} \\
{[\mathrm{~s}]}\end{array}$ & $\begin{array}{c}\begin{array}{c}\text { Reduction of } \\
\text { combustion } \\
\text { time }\end{array} \\
\text { depending } \\
\text { on Gs (Time } \\
\text { in Gs }=0 \mathrm{~kg} / \\
\text { m }^{2} \mathbf{s} \\
\text { reference } \\
\text { level) }\end{array}$ \\
\hline 850 & 254 & 276 & $-9 \%$ & 180 & $29 \%$ \\
\hline 750 & 312 & 244 & $22 \%$ & 196 & $37 \%$ \\
\hline 650 & 352 & 268 & $24 \%$ & 160 & $55 \%$ \\
\hline
\end{tabular}

\section{Summary and conclusions}

During the combustion process of all types of pellets without the participation of inert material as expected, the lowering of the temperature in the combustion chamber resulted in a longer pellet combustion time. Combustion of pellets from oak sawdust in a stream of inert material $\left(2,5 \mathrm{~kg} / \mathrm{m}^{2} \mathrm{~s}\right.$ and $\left.5 \mathrm{~kg} / \mathrm{m}^{2} \mathrm{~s}\right)$ intensifies the process of the loss of mass of the combusted pellets. The presence of inert material accelerates the loss of mass of pellets, as it increases the amount of air directly reaching the pellets by removing ash and gaseous combustion products from its surface. As a result of the inert material stream, the diffusion process in the reaction area is intensified, and the chemical reaction constantly increases. Contrary to expectations, in the case of pellets from sunflower husk and straw, combustion in a stream of inert material with its value of $2,5 \mathrm{~kg} / \mathrm{m}^{2} \mathrm{~s}$ lasts the longest at the highest temperature of the combustion chamber $\left(850^{\circ} \mathrm{C}\right)$. At this temperature, the ash softening temperature is exceeded and the straw pellets are sintered. During the increase of the stream of inert material in the case of sunflower husk pellets, the coating partially disintegrated, and in the case of straw pellets, the sinter was completely disintegrated. During the combustion of pellets from oak sawdust, it was noticed that the stronger parameter for the combustion process in comparison with the intensity of the inert material stream is the temperature itself. Increasing the temperature in the combustion chamber accelerates the mass loss of the pellets to a greater extent than increasing the stream of inert material. Experimental research indicates that pellets obtained from different types of biomass are characterized by a different nature of combustion in fluidized conditions. Ash of different types of biomass contains various amounts of alkali metal compounds that affect the softening and melting point of combustion residues. Therefore, it is necessary to operate biomass boilers adapted to the properties of biomass combusted. Incorrect operating temperatures of the boiler for the type of fuel supplied may cause corrosion and accumulation of sediments on the heating surfaces of boilers, as well as disrupting the work of circulatory fluidized bed boilers due to the change of particle size distribution of the layer material in the combustion chamber (formation of hard sinters of combustion residues similar in size to the particle introduced to the chamber). 


\section{References}

1. International Energy Agency, World Energy Outlook (2017)

2. Pawłowska, Projekt Polityki energetycznej Polski do 2050 roku, Biuletyn Urzędu Regulacji Energetyki, Urząd Regulacji Energetyki, nr 1, 7-14 (2015)

3. Act dated 20 February 2015, relating to renewable sources of energy, Law Gazette 2015, pos. 478 with further amendments (2015)

4. L. Szecówka; Ekologiczny efekt energetycznego wykorzystania biopaliw, Wydawnictwo Politechniki Częstochowskiej; Częstochowa (2009)

5. Ekspertyza EC BREC, Ekonomiczne i prawne aspekty wykorzystania odnawialnych źródeł energii w Polsce (EC BREC, 2004r);

6. T. Juliuszewski, Ogrzewanie biomasą, PWRiL, Poznań (2009)

7. P. Kowalik, Wytwarzanie energii elektrycznej z biomasy w warunkach polskich, V Konferencja Naukowo-Techniczna. Ogólnopolskie Forum Odnawialnych Źródeł Energii’ 98, Gdańsk, 13-15 października, (1998)

8. H. Kruczek, R. Miller, A. Tatarek, Spalanie i współspalanie biomasy - korzyści i zagrożenia, Gospodarka Paliwami i energią, nr 3 (2003)

9. W. Kotowski, Utylizacja i gospodarka odpadami, Wydawnictwo Triada, Bytom (2001)

10. G. Winnicka, A. Tramer, G. Świeca, Badania właściwości biomasy stałej do celów energetycznych, Instytut Chemicznej Przeróbki Węgla, Zabrze(2005)

11. E. Głodek, Spalanie i współspalanie biomasy - poradnik; Opole (2010)

12. M. Jakubiak, W. Kordylewski, Pelety podstawowym biopaliwem dla energetyki, Archiwum Spalania, Vol.8, Nr 3-4 (2008)

13. Z. Bis, W. Gajewski, R. Kobyłecki, L. Jestin, L. Lafanechere, Analiza porównawcza niskoemisyjnych technik spalania, Gospodarka Paliwami i Energią nr 6 (1997)

14. W. Nowak, M. Bednarek, Czysto i ekonomicznie. Działania Polski w zakresie spalania w cyrkulacyjnej warstwie fluidalnej cz. 1., Energetyka Cieplna i Zawodowa nr 4 (2013)

15. J. Ćwieląg, Kotły Foster Wheeler'a do spalania biomasy - aktualny stan i perspektywy rozwojowe, Bełchatów, (2011)

16. M. Kosowska-Golachowska, K. Wolski, W. Gajewski, A. Kijo-Kleczkowska, T. Musiał, K. Środa, Spalanie biomasy agro i leśnej w cyrkulacyjnej warstwie fluidalnej, Rynek Energii 3(124)/2016 (2016)

17. J. Bibrzycki, A. Katelbach-Woźniak, M. Niestrój, A. Szlęk, Wpływ szybkości nagrzewania na przebieg pirolizy mieszanek biomasy, Ciepłownictwo, ogrzewnictwo, odnawialne źródła energii, Politechnika Krakowska im. T. Kościuszki, Kraków 13-20 (2013)

18. S. Stelmach, R. Wasilewski, J. Figa, Zgazowanie biomasy-przykłady nowych technologii, Archiwum Gospodarki Odpadami i Ochrony Środowiska, Vol. 7 (2008)

19. P. Pełka, Erozja ziaren węgla spalanych w cyrkulacyjnej warstwie fluidalnej, Wydawnictwo Politechniki Częstochowskiej, Częstochowa (2013)

20. M. Całek, Analiza porównawcza spalania biomasy i paliwa węglowego w strumieniu materiału inertnego, Praca dyplomowa inżynierska, Częstochowa (2017) 